\title{
KEPUTUSAN KEUANGAN, UKURAN PERUSAHAAN, STRUKTUR KEPEMILIKAN DAN NILAI PERUSAHAAN PUBLIK DI INDONESIA
}

\author{
Sri Hasnawati ${ }^{*}$, Agnes Sawir ${ }^{2}$ \\ ${ }^{1}$ Fakultas Ekonomi dan Bisnis Universitas Lampung, Jalan Prof. Dr. Sumantri Brojonegoro No. 1 \\ Bandar Lampung 35145, Indonesia \\ ${ }^{2}$ Universitas Katolik Atma Jaya Jakarta, Jalan Jenderal Sudirman No. 51, Jakarta 12930, Indonesia \\ * Penulis Korespondensi; E-mail: sri_hasnawati2005@yahoo.com
}

\begin{abstract}
Abstrak
Penelitian ini bertujuan untuk menemukan bukti empiris pengaruh keputusan keuangan, ukuran perusahaan, dan struktur kepemilikan terhadap nilai perusahaan dalam tiga kondisi ekonomi, yaitu sebelum krisis, selama krisis, dan setelah krisis. Model yang digunakan adalah multiple regression. Penelitian dilakukan tahun 1992-2008 dengan sampel sebanyak 78 perusahaan publik dan 1.084 data. Hasil penelitian menjelaskan bahwa ukuran perusahaan dan keputusan tidak membayar dividen merupakan variabel yang paling mempengaruhi nilai perusahaan dalam tiga situasi ekonomi. Selain itu, kebijakan tidak membayar dividen berpengaruh negatif terhadap nilai perusahaan. Ada juga perbedaan nilai perusahaan yang signifikan dalam tiga situasi ekonomi. Berdasarkan temuan tersebut, dapat disarankan kepada perusahaan publik agar ukuran perusahaan penting untuk diperhatikan. Kebijakan membayar dividen kas dapat dipertimbangkan dalam upaya peningkatan nilai perusahaan.
\end{abstract}

Kata kunci: Keputusan keuangan, ukuran perusahaan, struktur kepemilikan, nilai perusahaan

\begin{abstract}
The objectives was to find empirical evidence of the influence financial decisions, firm size, and ownership structure on firm value in the three economic conditions (before, during, and after the crisis). The model was used multiple regression. The study was conducted in 1992-2008 with samples of 78 public companies and 1084 datas. The results explained that company size and decision not to pay dividends were most affected variables. In addition, policy not to pay dividends had negative effect on firm value. There were also significant differences of company value. For public companies, company's size should be considered. Policies of paying cash dividends could be considered in order to increase company value.
\end{abstract}

Keywords: Financing decision, company size, ownership structure, firm value

\section{Pendahuluan}

Tujuan utama perusahaan adalah meningkatkan nilai perusahaan melalui peningkatan kemakmuran pemilik atau pemegang saham perusahaan (Brigham, Gapenski, \& Daves, 2006). Pihak manajemen atau manajer perusahaan sering mempunyai tujuan lain, sehingga timbul konflik kepentingan antara manajer dan pemegang saham. Penyebab konflik antara manajer dan pemegang saham antara lain adalah dalam pembuatan keputusan yang berkaitan dengan aktivitas pencarian dana (financing decision) dan bagaimana dana yang diperoleh tersebut diinvestasikan.

Bursa Efek Indonesia (BEI) menyatakan hanya sebagian kecil porsi saham yang dijual kepada publik, sehingga kepemilikan perusahaan sangat terkonsentrasi pada sedikit pemegang saham. Pemegang saham terbesar adalah pengendali perusahaan. Kendali yang besar memudahkan para pemilik mengontrol berbagai kebijakan strategis, seperti strategi pendanaan. Claessens, Djankov, and Lang (2000) menyatakan bahwa belum terdapat pemisahan yang jelas antara kepemilikan dan kontrol pada perusahaan yang terdaftar di Bursa Efek Jakarta (BEI). Kebanyakan perusahaan masih dimiliki oleh keluarga dan posisi manajer dipegang oleh pemegang saham mayoritas atau manajernya dari kalangan keluarga. Akibatnya yang menjadi pendapat pemegang saham terbesar juga menjadi pendapat manajer.

Kebijakan manajemen berkaitan dengan kemakmuran dirinya dan kemakmuran pemilik perusahaan. Kebijakan seperti pendanaan dan struktur kepemilikan perusahaan merupakan topik yang telah banyak diteliti secara luas dalam teori keagenan. Dalam teori perusahaan, masalah keagenan (Jensen \& Meckling, 1976) selalu muncul di antara manajer, pemegang saham dan kreditur. Manajer sebagai pihak yang memiliki informasi paling lengkap dibandingkan 
pihak lainnya (adanya asimetri informasi) yang cenderung meningkatkan kemakmurannya dengan cara mengambil kebijakan-kebijakan yang menguntungkan dirinya.

Penentuan keputusan pendanaan dan dividen menurut Barclay, Smith, and Watts (1998) berkaitan dengan masalah free cash flow perusahaan. Perusahaan yang pertumbuhannya tinggi mempunyai kesempatan yang besar, memungkinkannya untuk membayar deviden yang rendah, karena mereka mempunyai kesempatan yang profitable dalam mendanai investasinya secara internal, sehingga perusahaan tidak tergoda untuk menggunakan utang. Menurut teori pecking order Myers (2001) dan Baskin (1989) pendanaan dapat dilakukan dengan urutan sumber dana yang memiliki risiko lebih kecil yaitu pertama laba ditahan, diikuti dengan hutang, dan yang terakhir ekuitas baru. Jadi, apabila dana internal tidak mencukupi, pendanaan melalui hutang akan menjadi pertimbangan yang dapat dipilih. Sebaliknya, perusahaan yang pertumbuhannya rendah berusaha menarik dana dari luar untuk mendanai investasinya dengan mengorbankan sebagian besar labanya dalam bentuk dividen maupun bunga.

Perkembangan teori keagenan memberikan pengakuan bahwa struktur kepemilikan perusahaan dapat mempengaruhi kinerja perusahaan dengan menyederhanakan konflik antara manajemen dengan pemegang saham (Putterman, 1993). Distribusi kepemilikan di antara kelompok-kelompok yang berbeda dapat berpengaruh pada oportunisme manajerial yang selanjutnya berimplikasi pada perilaku manajer dan kinerja perusahaan.

Terjadinya krisis ekonomi pada tahun 1997 di Indonesia menyebabkan banyak perusahaan mengalami penurunan nilai. Setiap perusahaan terutama perusahaan yang berinteraksi dengan pasar modal, sangat berkepentingan terhadap kemampuan mempertahankan kinerjanya. Kesulitan keuangan yang dihadapi menyebabkan banyak perusahaan melakukan restrukturisasi utang. Oleh karena itu, penelitian ini termotivasi untuk melakukan penelitian pengaruh keputusan keuangan, ukuran perusahaan dan struktur keuangan dengan nilai perusahaan. Dengan demikian, diharapkan di masa datang kesulitan keuangan yang timbul akibat dari keputusan keuangan yang tidak tepat dapat dihindari dan penentukan struktur kepemilikan dapat ditentukan lebih tepat.

Berdasarkan uraian di atas, maka formulasi pokok permasalahan penelitian dapat dirumuskan yakni 1) Bagaimana keputusan investasi, keputusan pendanaan, kebijakan dividen (keputusan keuangan), kepemilikan perseroan terbatas (PT), domestik/ institusi, kepemilikan publik, kepemilikan manajerial, dan kepemilikan asing mempengaruhi nilai perusahaan; 2) Bagaimana nilai perusahaan pada situasi sebelum krisis (1993-1997), selama krisis (1999-2003), dan setelah krisis (2004-2008). Sebagai catatan, tahun 2008 dimasukkan sebagai periode setelah krisis, karena tahun 2008 masih menghasilkan data yang mencerminkan nilai dan data pasca krisis tahun 1998.

Penelitian ini mempunyai tujuan untuk menemukan bukti empiris tentang pengaruh keputusan investasi, keputusan pendanaan, kebijakan dividen, kepemilikan perseroan terbatas (PT) domestik/ institusi, kepemilikan publik, kepemilikan manajerial, dan kepemilikan asing terhadap nilai perusahaan. Selanjutnya, penelitian ini juga bertujuan untuk menguji perbedaan nilai perusahaan sebelum krisis (1993-1997), selama krisis (1999-2003), dan setelah krisis (2004-2008).

Teori keagenan secara prinsip menggunakan asumsi utama bahwa pemilihan kebijakan perusahaan bertujuan untuk memaksimalkan nilai perusahaan. Konsep yang sangat kuat mengenai hubungan antara leverage dan biaya adalah konsep yang diperkenalkan oleh Jensen and Meckling (1976). Konsep tersebut menggambarkan perusahaan sebagai "nexus of relationship" yang dapat dikarakteristikkan sebagai principal-agent relationships. Hubungan principalagent menimbulkan biaya, karena ada kemungkinan agen tidak selalu menjalankan bisnis dengan cara yang konsisten sesuai kepentingan yang terbaik bagi principal (Jensen \& Meckling, 1976). Inti hubungan keagenan adalah adanya pemisahan antara kepemilikan (di pihak principal atau investor) dan pengendalian (di pihak agent atau manajer).

\section{Keputusan Investasi}

Investasi merupakan proksi untuk peluang pertumbuhan perusahaan. Keputusan investasi dalam penelitian ini diproksi dengan struktur aset. Variabel ini merupakan realisasi investasi yang dilakukan perusahaan pada tahun yang bersangkutan. Struktur aset perusahaan diukur dengan menggunakan hasil bagi antara aktiva tetap terhadap total aktiva (Titman \& Wessels, 1988; Thies \& Klock, 1992).

Peluang investasi ditentukan oleh line of business yang didasarkan oleh keunggulan bersaing. Perusahaan yang melakukan investasi pada proyek yang memiliki NPV (net present value) positif akan dapat meningkatkan kesejahteraan pemegang saham (nilai perusahaan). Berdasarkan argumen tersebut, maka penelitian ini memiliki hipotesis yakni keputusan investasi berpengaruh positif terhadap nilai perusahaan. 


\section{Keputusan Pendanaan}

Keputusan pendanaan adalah pemilihan struktur keuangan, yang menyangkut bauran pendanaan yang berasal dari modal sendiri dan utang yang akan digunakan oleh perusahaan. Pemilihan struktur keuangan ini pada akhirnya menyangkut penentuan banyaknya utang (leverage keuangan) yang akan digunakan oleh perusahaan untuk mendanai aktivanya. Pendanaan dengan modal sendiri maupun dengan menggunakan utang akan menimbulkan biaya. Biaya ini dikenal dengan istilah biaya modal.

Ada beberapa definisi tentang leverage. Definisi yang akan digunakan tergantung pada tujuan analisis (Rajan \& Zingales, 1995). Leverage dapat diukur dengan menggunakan nilai buku maupun dengan nilai pasar. Leverage didefinisikan sebagai rasio nilai buku utang terhadap nilai buku aktiva dalam penelitian ini. Hubungan antara struktur modal dan nilai perusahaan menjadi perdebatan, baik secara teoritis maupun dalam penelitian empiris. Modigliani and Miller $(1958,1963)$ menunjukkan bahwa dalam pasar sempurna tanpa pajak, leverage tidak ada hubungannya dengan nilai perusahaan. Apabila ada pajak, pembayaran bunga akan menimbulkan penghematan pajak, sehingga relasi antara nilai perusahaan dengan struktur modal adalah positif. Miller (1977) menambahkan pajak perorangan dalam analisisnya dan menunjukkan bahwa penggunaan utang yang optimal terjadi di tingkat makro, tetapi tidak terjadi pada tingkat perusahaan.

Penelitian lain menambahkan dalam pasar tidak sempurna, ada berbagai masalah yang mempengaruhi struktur modal optimal yang akan memaksimalkan nilai perusahaan, misalnya biaya kebangkrutan (Baxter \& Cragg, 1970; Stiglitz, 1972; Kraus \& Litzenberger, 1973; Kim, 1978), biaya keagenan (Jensen \& Meckling, 1976), dan keuntungan penghematan pajak karena penggunaan leverage (DeAngelo \& Masulis, 1980). Analisis-analisis mereka mengkukuhkan keberadaan struktur modal optimal. DeAngelo and Masulis (1980) menunjukkan dengan adanya substitusi penghematan pajak untuk utang (seperti depresiasi, amortisasi dan kredit pajak investasi). Oleh karena itu, setiap perusahaan mempunyai keputusan leverage optimal internal yang unik dengan atau tanpa biaya yang berhubungan dengan leverage. Berdasarkan argumen tersebut, hipotesis yang digunakan adalah keputusan pendanaan berpengaruh positif terhadap nilai perusahaan.

\section{Kebijakan Dividen}

Investor mempunyai tujuan untuk meningkatkan kesejahteraannya, yaitu dengan mengharapkan return dalam bentuk dividen dan capital gain. Kebijakan dividen pada hakikatnya adalah menentukan porsi keuntungan yang akan dibagikan kepada para pemegang saham dan yang akan ditahan sebagai bagian dari laba ditahan (Levy \& Sarnat, 1990). Pembuatan keputusan yang tepat dalam kebijakan dividen akan dapat memaksimumkan nilai perusahaan.

Manajemen membagikan dividen yang tinggi untuk menyampaikan informasi kepada pasar mengenai potensi masa depan perusahaan (Brickley, 1983). Easterbrook (1984) mengemukakan bahwa dividen merupakan alat bagi pemegang saham untuk mendorong manajemen agar mendapatkan modal di pasar yang kompetitif. Secara umum, pasar akan bereaksi positif apabila ada peningkatan dividen, sehingga diharapkan nilai perusahaan meningkat. Berdasarkan argumen tersebut, dapat dirumuskan hipotesis yakni kebijakan membayar dividen berpengaruh positif terhadap nilai perusahaan. Hipotesis lainnya adalah kebijakan tidak membayar dividen berpengaruh negatif terhadap nilai perusahaan.

\section{Ukuran Perusahaan}

Ukuran perusahaan dinyatakan sebagai determinan dari struktur keuangan dalam hampir setiap studi dan untuk sejumlah alasan berbeda. Ukuran perusahaan dapat menentukan tingkat kemudahan perusahaan dalam memperoleh dana dari pasar modal dan menentukan kekuatan tawar-menawar (bargaining power) dalam kontrak keuangan. Perusahaan besar biasanya dapat memilih pendanaan dari berbagai bentuk utang, termasuk penawaran spesial yang lebih menguntungkan dibandingkan dengan perusahaan kecil. Semakin besar jumlah uang yang terlibat, semakin memungkinkan membuat kontrak yang dapat dirancang sesuai dengan preferensi kedua pihak, sebagai ganti dari penggunaan kontrak standar utang.

Moh'd, Perry, \& Rimbey (1998) mengemukakan bahwa perusahaan yang berukuran besar akan lebih mudah mengakses pendanaan melalui pasar modal. Kemudahan ini merupakan informasi baik bagi pengambilan keputusan investasi dan juga dapat merefleksikan nilai perusahaan di masa mendatang. Ukuran perusahaan menggambarkan besar kecilnya suatu perusahaan yang dapat dinyatakan dengan total aktiva atau total penjualan bersih. Semakin besar total aktiva maupun penjualan, maka semakin besar pula ukuran suatu perusahaan. Prasetyorini (2013) menemukan dalam penelitiannya bahwa ukuran perusahaan berpengaruh positif terhadap nilai perusahaan. Sejalan dengan Sujoko dan Soebiantoro (2007) menemukan bahwa ukuran perusahaan berpengaruh 
positif terhadap nilai perusahaan. Temuan ini juga konsisten dengan penelitian yang dilakukan oleh Soliha dan Taswan (2002) yang menyatakan bahwa ukuran perusahaan berpengaruh positif terhadap nilai perusahaan. Penelitian Rachmawati dan Triatmoko (2007) juga menyatakan bahwa ukuran perusahaan dinyatakan berhubungan positif dan signifikan terhadap nilai perusahaan. Berdasarkan argumen tersebut, dapat dirumuskan hipotesis yakni ukuran perusahaan berpengaruh positif terhadap nilai perusahaan.

\section{Struktur Kepemilikan}

Beberapa studi (Short \& Keasey, 1999; Morck, Shleifer, \& Vishny, 1988; McConnell \& Servaes, 1995) menunjukkan adanya hubungan antara kepemilikan saham oleh manajemen dengan nilai perusahaan. Berbagai macam konflik kepentingan antara pihak-pihak yang berkepentingan atas perusahaan (stakeholder) dapat meningkat dan mempengaruhi pendanaan dan kinerja perusahaan.

Bukti empiris yang berkaitan dengan hubungan antara kepemilikan manajemen dan kinerja perusahaan masih beragam. Beberapa penelitian menunjukkan bahwa kepemilikan manajemen berpengaruh positif terhadap kinerja perusahaan (Demsetz \& Lehn, 1985). McConnell and Servaes (1995) menunjukkan bahwa hubungan antara kepemilikan manajemen dan kinerja berbentuk non-linier. Hal tersebut berbeda dengan penelitian Himmelberg, Hubbard, and Palia (1999) dengan menggunakan fungsi linier, menunjukkan tidak ada keterkaitan antara kepemilikan manajemen dan kinerja perusahaan. Mueller and Warneryd (2001) menyatakan bahwa perusahaan yang memiliki konsentrasi kepemilikan pada pihak dalam (insider ownership) memiliki kinerja yang lebih baik dibandingkan yang sebaliknya (outsider ownership). Holderness, Kroszner, and Sheehan (1999) menemukan adanya peningkatan kepemilikan manajemen pada perusahaan-perusahaan publik. Peningkatan kepemilikan ini dipicu oleh teori keagenan yang menyatakan bahwa semakin banyak saham yang dimiliki oleh pihak manajemen, maka semakin kecil konflik kepentingan antara pemegang saham dan manajemen.

La Porta, Lopez, Shleifer, and Vishny (1999) menunjukkan bahwa perusahaan yang terdapat di 27 negara yang menjadi sampel penelitiannya lebih banyak dimiliki oleh keluarga yang menjadi pemegang saham mayoritas dan mengendalikan perusahaan melalui cash flow rights. Pemisahan fungsi antara pemilik dan pengelola dapat menimbulkan masalah keagenan, sehingga diperlukan pengaturan yang optimal (Fama \& Jensen, 1983). Umumnya, perusahaan di Indonesia dijalankan oleh manajemen yang merangkap sebagai pemilik mayoritas dan masih mempunyai hubungan keluarga. Komposisi manajemen yang merangkap sebagai pemilik mayoritas akan menyebabkan kepentingan pemilik saham minoritas tidak terlindungi.

Kelompok usaha/institusi di Indonesia menguasai sekitar 60\% dari perusahaan yang diteliti dalam riset ini. Leff (1978) berpendapat bahwa kelompok usaha (business groups) dapat lebih menguntungkan dibandingkan perusahaan independen dalam beberapa kondisi. Kelompok usaha dapat memanfaatkan ketidaksempurnaan pasar terutama di pasar modal yang sedang berkembang (emerging market) dengan melakukan transaksi dalam kelompok usaha (intragroup) dan mencoba mengurangi biaya transaksi tersebut. Kelompok usaha juga mempunyai lebih banyak informasi mengenai perusahaan yang menjadi anggota kelompoknya dibandingkan investor luar, sehingga dapat memonitor lebih efektif dan lebih efisien. Bathala, Moon, and Rao (1994) menemukan bahwa kepemilikan institusional menggantikan kepemilikan manajerial dalam mengontrol agency cost. Semakin besar kepemilikan institusi, maka semakin besar kekuatan suara dan dorongan institusi untuk mengawasi manajemen. Akibatnya hal itu akan memberikan dorongan yang lebih besar untuk mengoptimalkan nilai perusahaan, sehingga kinerja perusahaan juga akan meningkat. Penelitian Barclay and Holderness (1990) menemukan bahwa tingkat kepemilikan institusional berpengaruh positif signifikan terhadap nilai perusahaan.

Pemegang saham pengendali yang besar dalam suatu kelompok usaha dapat memiliki insentif untuk mengalokasikan sumber daya bagi keuntungannya. Sebagai contoh, dalam kasus sumber daya perusahaan besar yang tercatat di bursa ditransfer kepada perusahaan kecil anggota kelompok usaha yang tidak tercatat di bursa. Keuntungan pribadi pemegang saham pengendali dapat melebihi biaya pribadinya ketika sumber daya ditransfer. Ketika disparitas antara kepemilikan dan pengelolaan kelompok usaha meningkat, permasalahan ini akan meningkat (Wiwattanakantang, 2001). Perusahaan-perusahaan konglomerat dapat merealokasikan modalnya dari satu perusahaan ke perusahaan lain atau melakukan transfer dari sebuah divisi ke divisi lain dalam perusahaan multidivisional.

Scharfstein (1998) berpendapat bahwa realokasi pada perusahaan multi divisional yang terdiversifikasi akan menurunkan kinerja, karena menimbulkan ketidakefisienan modal, khususnya apabila modal 
over-invested dalam divisi yang lemah dan underinvested dalam divisi yang kuat. Modal dapat juga ditransfer dari perusahaan yang kuat ke perusahaan lain yang lemah dalam kelompok usaha atau dari satu perusahaan yang pemegang saham pengendalinya mempunyai sedikit kepentingan ke perusahaan yang memiliki kepentingan lebih besar. Ketika sumber daya dialokasikan dalam proyek-proyek untuk keuntungan pribadi pemegang saham pengendali daripada untuk memaksimumkan nilai perusahaan, produktivitas marginal modal akan lebih rendah. Secara umum, ketika seorang pemegang saham pengendali yang oportunistik mengejar keuntungan pribadinya lebih daripada overall profitability, maka alokasi sumber daya akan terdistorsi dan efisiensi akan lebih rendah.

Salvatore (2005) menyatakan bahwa sebuah portofolio yang mengandung saham-saham domestik dan asing menawarkan risiko yang lebih rendah. Selain itu, tingkat pengembalian yang lebih tinggi bagi investornya dibanding portofolio yang hanya mengandung saham-saham domestik.

Lins (2003) menunjukkan bahwa pemisahan antara manajemen dan pemilik berpengaruh negatif terhadap nilai perusahaan pada negara-negara yang proteksi terhadap pemegang saham minoritasnya rendah. Sisi lainnya adalah pengaruh konsentrasi kepemilikan pada pihak luar perusahaan berpengaruh positif terhadap nilai perusahaan. Lemmon and Lins (2003) menunjukkan bahwa selama periode krisis, nilai Tobin's $q$ untuk perusahaan yang memiliki pemegang saham minoritas lebih rendah dibandingkan yang sebaliknya. Berdasarkan argumen tersebut, dapat dirumuskan hipotesis yakni; 1) Kepemilikan asing berpengaruh positif terhadap nilai perusahaan; 2) Kepemilikan manajer berpengaruh positif terhadap nilai perusahaan; 3) Kepemilikan publik berpengaruh negatif terhadap nilai perusahaan; 4) Kepemilikan PT (perseroan terbatas) domestik/institusi berpengaruh positif terhadap nilai perusahaan.

\section{Masa Sebelum Krisis (1993-1997), Selama Krisis (1999-2003), dan Setelah Krisis (2004-2008)}

Saat masa sebelum krisis, dinamika perekonomian Indonesia yang tinggi dengan nilai tukar rupiah yang stabil serta laju inflasi yang menurun disertai surplus neraca pembayaran yang cukup besar telah mendorong para investor baik dalam maupun luar negeri untuk berinvestasi di Indonesia. Dana dari luar negeri mengalir ke Indonesia baik dalam bentuk investasi langsung maupun dalam bentuk dana pinjaman kepada investor dalam negeri. Dana luar negeri tersebut semakin membesar jumlahnya, karena sebagian dana tersebut digunakan untuk menggantikan pinjaman dari perbankan dalam negeri sebagai akibat dari penerapan legal lending limit oleh Bank Indonesia.

Memasuki pertengahan tahun 1997, situasi moneter berubah dengan cepat sebagai akibat terjadinya krisis nilai tukar Baht di Thailand yang kemudian menyebar ke negara Asean lainnya termasuk Indonesia dan Korea Selatan. Nilai tukar rupiah mengalami tekanan karena menurunnya kepercayaan investor asing terhadap perekonomian Indonesia, yang mempunyai kesamaan karakteristik masalah perekonomian dengan Thailand.

Dalam upaya pemulihan kepercayaan masyarakat, pemerintah mengeluarkan kebijakan penjaminan menyeluruh terhadap kewajiban bank (blanket guarantee schemee). Guna menyehatkan perbankan pemerintah menempuh langkah restrukturisasi perbankan terutama melalui program rekapitalisasi dan mendirikan Badan Penyehatan Perbankan Nasional (BPPN). Kebijakan tersebut secara bertahap telah dapat meredam krisis perbankan.

Proses pemulihan kondisi perbankan berjalan sangat lambat, karena kompleks serta besarnya skala permasalahan yang dihadapi sebagai akibat ketidakseimbangan neraca di sektor perbankan dan banyaknya nasabah dari bank yang bermasalah. Selain itu juga karena pemberian kredit yang tidak didasarkan pada azas-azas perbankan yang sehat. Hal ini tercermin dari pemberian kredit yang berlebihan kepada kelompok tertentu dan kelompok terkait dengan bank yang mengakibatkan banyaknya pelanggaran batas minimum pemberian kredit (BMPK). Masalah lain adalah banyaknya sumber dana jangka pendek yang berasal dari luar negeri tanpa lindung nilai (hedging) yang ditanam pada proyek-proyek jangka panjang dan tidak menghasilkan devisa. Dalam rangka mempercepat penyelesaian kredit bermasalah, Satuan Tugas (Sagas) restrukturisasi kredit dibentuk Bank Indonesia pada bulan Desember 1998.

Kinerja perbankan pada tahun 1999 telah menunjukkan perkembangan ke arah perbakan, meskipun masih mengalami tahapan-tahapan yang sulit dalam rangka konsolidasi dan menyeimbangkan posisi keuangan. Sejak Juni 1999, bank-bank telah memperoleh positive spread, sehingga kerugian operasional bank semakin mengecil. 
Tabel 1

Deskriptif Statistik Variabel Penelitian

\begin{tabular}{lrrrrr}
\hline \multicolumn{1}{c}{ Variable } & $N$ & Minimum & Maximum & Mean & \multicolumn{1}{c}{ Std. Deviation } \\
\hline MBV (\%) & 1084 & 31,23 & 882,86 & 128,89 & 86,08 \\
StrA (\%) & 1084 & 6,49 & 98,22 & 39,02 & 18,84 \\
Blev $(\%)$ & 1084 & 4,1 & 99,92 & 52,69 & 21,58 \\
DivME $(\%)$ & 1084 & 0 & 47,05 & 2,46 & 4,62 \\
OwnPT (\%) & 1084 & 0 & 97,28 & 38,68 & 30,68 \\
OwnP (\%) & 1084 & 1 & 97,97 & 27,69 & 16,65 \\
OwnM (\%) & 1084 & 0 & 84,44 & 5,23 & 13,79 \\
OwnA (\%) & 1084 & 0 & 98 & 23,82 & 31,33 \\
Sales (Rp 000.000) & 1084 & 7943,28 & 70794578 & 1640951,93 & 5059974,25 \\
\hline
\end{tabular}

Perkembangan pertumbuhan ekonomi Indonesia mengalami percepatan dalam periode 2004-2008. Pemerintah hasil pemilihan umum yang demokratis berhasil menciptakan stabilitas ekonomi makro yang tercermin dari nilai tukar dan laju inflasi dan indikator utama perekonomian lainnya. IHSG di BEI meningkat, perkembangan IHSG dalam periode 1993-2008 dapat dilihat pada Tabel 1. Kondisi ekonomi global yang tertekan dan penuh ketidakpastian menyebabkan terjadi gejolak di pasar modal. Hal ini menyebabkan Indeks harga saham gabungan (IHSG) sempat mengalami penurunan cukup besar di awal tahun 2007, walaupun kinerja pasar modal Indonesia lebih baik dari negara lain. Berdasarkan argumen tersebut dapat dirumuskan hipotesis yakni adanya perbedaan nilai perusahaan sebelum krisis (1993-1997), selama krisis (1999-2003), dan setelah krisis (2004-2008).

\section{Metode Penelitian}

Populasi penelitian ini adalah perusahaanperusahaan manufaktur yang terdaftar di Bursa Efek Jakarta. Sampel yang diteliti adalah data yang tersedia pada tahun 1993 sampai dengan tahun 1997 (periode sebelum krisis ekonomi), tahun 1999 sampai dengan tahun 2003 (periode krisis ekonomi), dan tahun 2004 sampai dengan 2008 (periode setelah krisis ekonomi). Pendekatan dalam pengambilan sampel penelitian adalah purposive sampling. Adapun kriteria pengambilan sampel adalah 1) Perusahaan adalah perusahaan manufaktur yang terdaftar di BEJ selama tahun 1993 sampai dengan tahun 2003. 2) Saham perusahaan tergolong aktif diperdagangkan di BEJ. 3) Perusahaan mempublikasi laporan keuangan yang telah diaudit engan menggunakan tahun buku yang berakhir pada tanggal 31 Desember. 4) Memiliki data yang dibutuhkan untuk pengukuran variabel penelitian. Periode pengambilan sampel ditentukan dengan alasan bahwa perusahaan go public tersebut tercatat pada periode penelitian yaitu periode sebelum krisis, saat krisis dan pasca krisis dengan data yang memadai. Berdasarkan kriteria tersebut, maka 78 perusahaan terpilih sebagai sampel.

Sesuai dengan masalah dan hipotesis yang akan diuji, maka variabel-variabel yang akan diteliti dalam penelitian ini adalah 1) Keputusan investasi diproksi dengan struktur aset. Variabel ini diukur dengan menggunakan hasil bagi antara aktiva tetap dengan total aktiva dan dinyatakan dalam persentase $(P P E / A)_{t-\text { I. }}$ 2) Keputusan pendanaan diproksi dengan book value leverage. Variabel ini diukur dengan menggunakan hasil bagi antara nilai buku utang dengan total aktiva dan dinyatakan dalam persentase $(D / A)_{t-1}$. 3) Kebijakan dividen dinyatakan dengan dua variabel, yaitu $D i v E$ dan $D i v D$. DivE adalah dividen tunai (cash dividend) dibandingkan dengan nilai pasar ekuiti dan dinyatakan dalam persentase $(D i v / M E)_{t-1}$. Dalam rangka melihat pengaruh kebijakan dividen, apabila perusahaan tidak membayar dividen, maka variabel ini dinyatakan dengan $(\operatorname{Div} D)_{t-1 .}$. DivD adalah dummy variable yang diberi nilai 1 apabila perusahaan pada tahun yang bersangkutan tidak membayar dividen dan 0 apabila perusahaan membayar dividen (DivE). 4) Ukuran perusahaan pada $t$-1 dinyatakan dengan (logSales) $)_{t-1 .}$ 5) Nilai pasar perusahaan diproksi dengan Tobin's $q$. Tobin's $q$ dihitung dengan $(M / B)_{t}=($ Nilai total aset - Nilai buku ekuitas + Nilai pasar ekuitas)/Nilai buku total aset masing-masing pada $t$. Nilai pasar ekuitas $=$ Jumlah saham beredar $\mathrm{x}$ harga saham rata-rata tertimbang harian. Nilai buku ekuitas $=$ Nilai buku ekuitas pada akhir tahun fiskal. Nilai total aset $=$ Nilai buku total aset pada akhir tahun fiskal. 6) Struktur kepemilikan.

Struktur kepemilikan dibagi menjadi empat bentuk kepemilikan sesuai dengan data kepemilikan saham yang ada, yaitu: 1) Kepemilikan PT domestik (instutusi) diukur dengan total persentase kepemilikan saham oleh PT (perseroan terbatas) dalam negeri 
(Indonesia) $(O w n P T)_{t-1 .}$ 2) Kepemilikan publik diukur dengan total persentase kepemilikan saham oleh publik $(O w n P)_{t-1 .}$ 3) Kepemilikan manajer diukur dengan total persentase kepemilikan saham oleh pemegang saham yang aktif dalam kepeminpinan perusahaan sebagai manajer atau dewan komisaris $(O w n M)_{t-1 .}$ 4) Kepemilikan asing diukur dengan total persentase kepemilikan saham oleh PMA (penanaman modal asing), institusi asing maupun investor asing $(O w n A)_{t-1}$.

Data penelitian dianalisis dengan menggunakan model regresi sebagai berikut:

$$
\begin{aligned}
& \left(\frac{M}{B}\right)_{t}=a+b\left(\frac{P P E}{A}\right)_{t-1}+c\left(\frac{D}{A}\right)_{t-1}+d\left(\frac{D i v}{M E}\right)_{t-1}+ \\
& e(\text { DivD })_{t-1}+f \log S_{t-1}+g(\text { OwnPT })_{t-1}+ \\
& h(\text { OwnP })_{t-1}+i(\text { OwnM })_{t-1}+j(\text { OwnA })_{t-1}+u_{t}
\end{aligned}
$$

Time lag 1 tahun digunakan dalam penelitian ini, karena diperkirakan keputusan investasi, keputusan pendanaan, kebijakan dividen, dan struktur kepemilikan berpengaruh terhadap nilai perusahaan tahun berikutnya.

Sebelum dilakukan analisis regresi untuk menguji hipotesis penelitian terlebih dahulu dilakukan pengujian asumsi klasik. Distribusi data yang tidak berbentuk kurva normal yang melanggar asumsi normalitas akan dijadikan bentuk yang normal dengan cara trimming (memangkas) observasi yang bersifat outlier. Besarnya sampel dalam penelitian ini ( $\mathrm{n}>30$ ), maka data akan dipangkas apabila nilainya lebih kecil daripada $\mu-3 \sigma$ atau lebih besar daripada $\mu$ $+3 \sigma$.

\section{Hasil Penelitian dan Pembahasan}

Data penelitian yang digunakan diambil dari tahun 1992 sampai 2008. Karakteristik sampel dari setiap variabel yang diteliti dapat dilihat pada Tabel 1 .
Berdasarkan seluruh sampel sebesar 1.084 data, perusahaan yang membayar dividen selama periode pengamatan sebanyak 588 dan perusahaan yang tidak membagi dividen sebanyak 496.

Hasil analisis regresi yang telah memenuhi asumsi klasik disajikan pada Tabel 2.

\section{Periode Sebelum Krisis (1993-1997)}

Uji $F$ persamaan regresi sebelum krisis menunjukkan hasil yang signifikan. Artinya variabel bebas dalam penelitian ini secara bersama-sama mempengaruhi varabel terikat. Hasil uji parsial (uji $t$ ) menunjukkan bahwa keputusan investasi, keputusan pendanaan, kebijakan dividen, kepemilikan publik dan kepemilikan asing berpengaruh negatif terhadap nilai perusahaan, sedangkan ukuran perusahaan berpengaruh positif. Variabel tidak membagi dividen, kepemilikan PT domestik, dan kepemilikan manajer tidak berpengaruh terhadap nilai perusahaan. Hasil tersebut menunjukkan bahwa kebijakan investasi yang dilakukan belum memberikan nilai bagi perusahaan. Kebijakan pendanaan mengarah pada risiko keuangan yang makin meningkat, karena dengan meningkatnya hutang perusahaan beban tetap perusahaan untuk membayar bunga hutang makin besar sementara hasil investasi yang diharapkan belum tercapai. Variabel kepemilikan asing dan kepemilikan publik berpengaruh negatif terhadap nilai perusahaan, karena kepemilikan saham menyebar sehingga kontrol pemegang saham mayoritas menjadi dominan dalam mengambil keputusan (misalnya akuisisi internal) yang berdampak terhadap penurunan nilai perusahaan. Kepemilikan asing berpengaruh negatif terhadap nilai perusahaan karena investor asing menanamkan dananya hanya sementara (hot money) di Indonesia, sehingga tidak mampu meningkatkan nilai perusahaan. Berdasarkan hasil regresi ditunjukkan bahwa selama periode sebelum krisis dari

Tabel 2

Hasil Uji Regresi Market Book Value

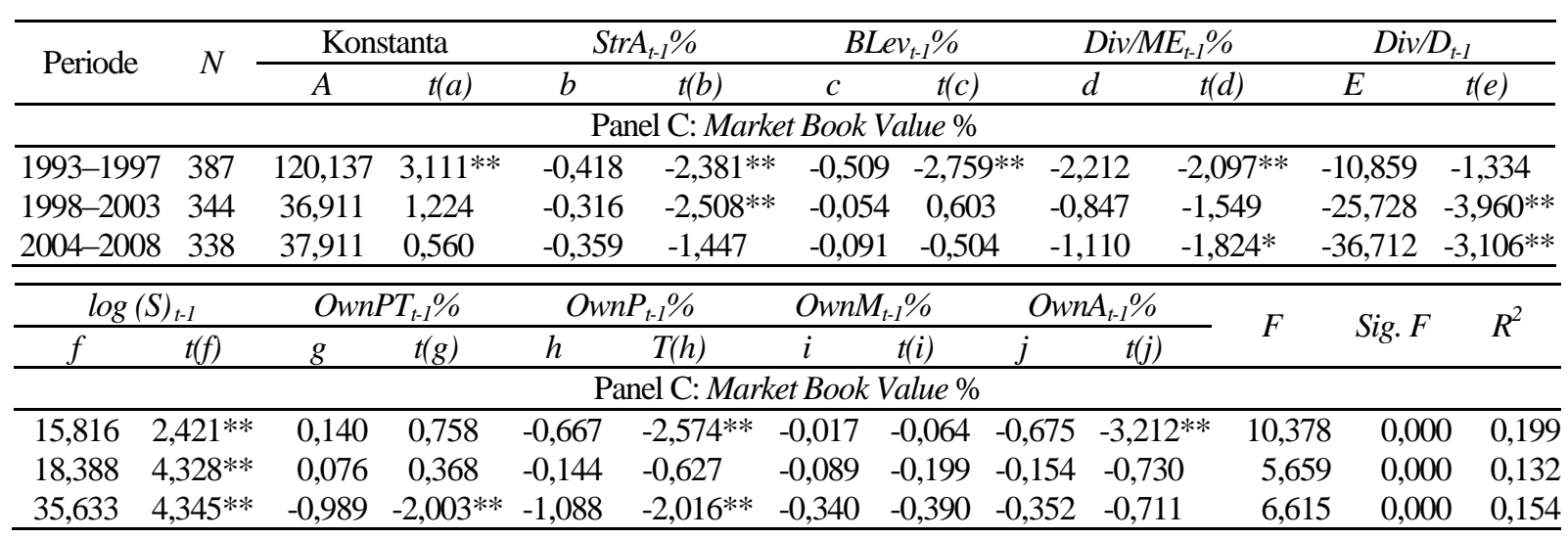


sembilan variabel bebas yang diamati. Variabel ukuran perusahaan paling dominan mempengaruhi nilai perusahaan dengan nilai koefisien parameter sebesar 15,816. Kebijakan membayar dividen berpengaruh signifikan sebesar 2,215. Hasil ini dapat dikatakan bahwa pada periode sebelum krisis pembayaran dividen justru menurunkan nilai perusahaan.

\section{Periode Selama Krisis (1999-2003)}

Uji $F$ persamaan regresi dengan $\alpha 5 \%$, pada periode krisis menunjukkan hasil yang signifikan. Artinya variabel bebas dalam penelitian ini secara bersama-sama mempengaruhi nilai perusahaan. Berdasarkan persamaan tersebut uji parsial (uji $t$ ), dihasilkan keputusan investasi dan tidak membayar dividen berpengaruh negatif terhadap nilai perusahaan. Ukuran perusahaan berpengaruh positif, sedangkan variabel lain tidak mempengaruhi nilai perusahaan. Hasil tersebut menunjukkan bahwa investasi yang dilakukan tidak mampu meningkatkan nilai perusahaan sesuai dengan yang diharapkan ( $N P V$ negatif) akibat krisis ekonomi. Kebijakan tidak membayar dividen ditangkap sebagai sinyal negatif oleh investor. Hasil ini dapat menjelaskan bahwa ketika masa krisis investasi yang menjanjikan keuntungan sangat kecil. Dalam situasi ini, investor mangharapkan dividen dibayarkan kepada para pemegang saham. Ukuran perusahaan berpengaruh positif terhadap nilai perusahaan karena ada kebijakan pemerintah melakukan restrukturisasi hutang bagi perusahaan-perusahaan besar. Selama periode krisis, faktor dominan yang berpengaruh terhadap nilai perusahaan adalah kebijakan tidak membayar dividen dengan nilai koefisien parameter sebesar -25,728 dan ukuran perusahaan dengan koefisien parameter sebesar 18,388. Variabel yang tidak berpengaruh terhadap nilai perusahaan adalah keputusan pendanaan, karena dalam banyak kasus nilai ekuitas perusahaan sudah negatif. Utang perusahaan lebih besar daripada asetnya (bangkrut secara teknis).

\section{Periode Setelah Krisis (2004-2008)}

Uji $F$ persamaan regresi dengan $\alpha 5 \%$, pada periode krisis menunjukkan hasil yang signifikan. Artinya secara bersama-sama variabel bebas dalam penelitian ini mempengaruhi nilai perusahaan. Berdasarkan persamaan tersebut, dilakukan uji parsial (uji t) dengan $\alpha=5 \%$. Hasilnya adalah kebijakan tidak membayar dividen, kepemilikan PT domestik, dan kepemilikan publik berpengaruh negatif terhadap nilai perusahaan. Ukuran perusahaan berpengaruh positif terhadap nilai perusahaan. Kelima variabel lainnya tidak berpengaruh terhadap nilai perusahaan. Ukuran perusahaan berpengaruh positif terhadap nilai perusahaan. Hal ini dapat terjadi karena pasar menganggap makin besar ukuran perusahaan, maka kemampuan perusahaan makin tinggi dalam melakukan kegiatan atau kesempatan investasi yang lebih luas yang akhirnya dapat meningkatkan nilai perusahaan. Kebijakan tidak membayar dividen berpengaruh negatif terhadap nilai perusahaan. Hasil penelitian ini menunjukkan bahwa investor lebih mengharapkan pembayaran dividen kas yang dianggap lebih menguntungkan bagi investor. Kepemilikan PT domestik dan publik juga berpengaruh negatif terhadap nilai perusahaan. Mueller and Warneryd (2001) menyatakan bahwa perusahaan yang memiliki konsentrasi kepemilikan pada pihak dalam (insider ownership) akan memiliki kinerja lebih baik dibandingkan yang sebaliknya (outsider ownership). Konsentrasi kepemilikan pihak dalam dapat memotivasi meningkatkan kinerja perusahaan lebih optimal. Dengan demikian, dapat dikatakan bahwa perusahaan publik di Indonesia khususnya manufaktur lebih banyak didominasi oleh kepemilikan outsider ownership. Kepemilikan PT domestik (institusi) apabila dianggap sebagai insider ownership (McConnell \& Servaes, 1995; Scharfstein, 1998). Artinya adalah awalnya mampu meningkatkan nilai perusahaan, namun pada suatu titik tertentu akan berbalik menjadi negatif pengaruhnya terhadap nilai perusahaan. Perusahaan-perusahaan konglomerat di Indonesia dapat merealokasikan modalnya dari satu perusahaan ke perusahaan lain, melakukan transfer dari sebuah divisi ke divisi lain dalam perusahaan multidivisional membuat munculnya kepemilikan PT domestik (institusional).

Saat situasi pasca krisis, faktor yang paling mempengaruhi nilai perusahaan adalah tidak membayar dividen dan ukuran perusahaan. Masingmasing memiliki koefisien parameter sebesar -36,712 dan 35,633. Nilai paling kecil mempengaruhi nilai perusahaan dari sembilan variabel yang diamati adalah kebijakan pendanaan dengan koefisien parameter sebesar -0,091. Rincian hasil uji regresi untuk setiap tahun dapat dilihat pada Tabel 4. Pengujian hipotesis lainnya dari penelitian ini adalah ingin mengetahui apakah ada perbedaan nilai perusahaan dalam ketiga situasi ekonomi yang diamati. Hasil uji regresi diperlihatkan pada Tabel 3 .

Hasil analisis statistik menunjukkan bahwa nilai perusahaan memiliki perbedaan yang signifikan selama periode sebelum krisis, selama krisis dan setelah krisis. Dengan kata lain, dapat dikatakan bahwa nilai perusahaan manufaktur di pasar modal Indonesia dipengaruhi oleh situasi ekonomi yang terjadi. 
Tabel 3

Hasil Uji Perbedaan Data Tiap Periode Regresi Market Book Value

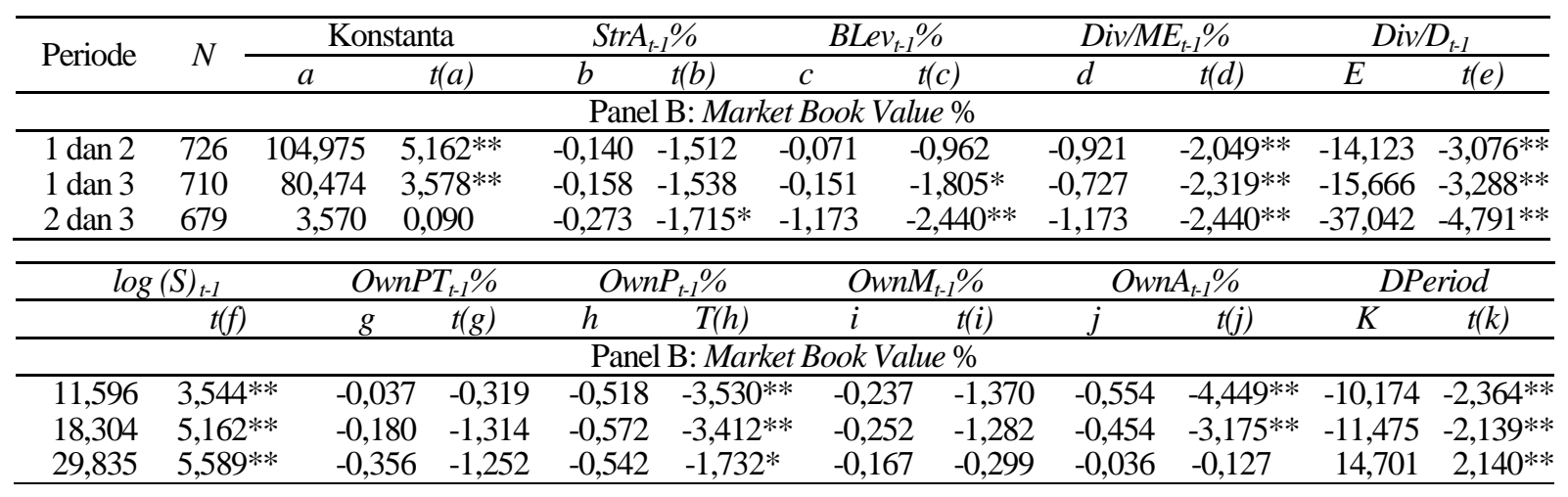

\begin{tabular}{|c|c|c|}
\hline$F$ & Sig. $F$ & $R^{2}$ \\
\hline \multicolumn{3}{|c|}{ Panel B: Market Book Value \% } \\
\hline 11,830 & 0,000 & $\overline{0,142}$ \\
\hline 7,852 & 0,000 & 0,101 \\
\hline 9,635 & 0,000 & 0,126 \\
\hline
\end{tabular}

Keterangan: *) signifikan pada $\alpha=10 \%$;**) signifikan pada $\alpha=5 \%$

Periode 1 (1993-1997); Periode 2 (1998-2003); Periode 3 (2004-2008)

Tabel 4

Hasil Uji Regresi Market Book Value

\begin{tabular}{|c|c|c|c|c|c|c|c|c|c|c|c|}
\hline \multirow{2}{*}{ Tahun } & \multirow[b]{2}{*}{$N$} & \multicolumn{2}{|c|}{ Konstanta } & \multicolumn{2}{|c|}{$\operatorname{StrA}_{t-1} \%$} & \multicolumn{2}{|c|}{ BLev $_{t-1} \%$} & \multicolumn{2}{|c|}{ Div/ME $E_{t-1} \%$} & \multicolumn{2}{|c|}{$\overline{D i v} / D_{t-1}$} \\
\hline & & $a$ & $t(a)$ & $b$ & $t(b)$ & $c$ & $t(c)$ & $d$ & $t(d)$ & $e$ & $t(e)$ \\
\hline \multicolumn{12}{|c|}{ Panel A: Market Book Value \% } \\
\hline 1993 & 65 & 337,689 & $4,296 * *$ & $-0,309$ & $-0,891$ & 0,219 & 0,521 & $-1,914$ & $-0,877$ & $-23,140$ & 0,337 \\
\hline 1994 & 73 & 241,335 & $3,934 * *$ & $-0,099$ & $-0,380$ & $-0,349$ & $-1,297$ & 1,788 & 1,014 & 1,669 & 0,141 \\
\hline 1995 & 78 & $-83,008$ & $-0,819$ & $-0,958$ & $-2,158 * *$ & $-0,856$ & $-2,022 * *$ & $-1,764$ & $-0,506$ & 57,406 & $1,971^{*}$ \\
\hline 1996 & 77 & 75,375 & 1,299 & 0,015 & 0,053 & $-0,228$ & $-0,882$ & $-0,296$ & $-0,279$ & $-29,917$ & $-2,062 * *$ \\
\hline 1997 & 73 & 42,142 & 1,013 & $-0,203$ & $-1,174$ & 0,015 & 0,083 & 0,143 & 0,078 & $-4,294$ & $-0,442$ \\
\hline 1998 & 67 & 30,697 & 0,869 & $-0,085$ & $-0,624$ & 0,246 & $1,830 *$ & 14,264 & $5,969 * *$ & 9,436 & 0,812 \\
\hline 1999 & 67 & 184,474 & $4,654 * *$ & $-0,161$ & $-1,048$ & 0,001 & 0,008 & $-1,488$ & $-2,649 * *$ & $-49,011$ & $-3,591 * *$ \\
\hline 2000 & 63 & $-137,916$ & $-1,311$ & $-0,507$ & $-1,385$ & 0,104 & 0,406 & 1,389 & 0,799 & $-32,860$ & $-1,775^{*}$ \\
\hline 2001 & 66 & $-224,938$ & $-1,629$ & $-0,710$ & $-1,358$ & $-0,110$ & $-0,371$ & $-3,512$ & $-1,407$ & $-43,521$ & $-1,767^{*}$ \\
\hline 2002 & 56 & $-3,539$ & $-0,073$ & $-0,106$ & $-0,556$ & 0,150 & 0,891 & 4,381 & $3,722 * *$ & 4,381 & 0,406 \\
\hline 2003 & 64 & $-3,138$ & $-0,107$ & 0,129 & 1,000 & 0,021 & 0,159 & $-2,787$ & $-3,186^{* *}$ & $-37,590$ & $-5,027 * *$ \\
\hline 2004 & 66 & $-20,136$ & $-0,362$ & $-0,292$ & $-1,166$ & 0,264 & 0,980 & 5,412 & $1,756^{*}$ & 6,023 & 0,298 \\
\hline 2005 & 71 & 1334,217 & $4,530^{* *}$ & 0,228 & 0,262 & $-0,431$ & $-1,166$ & $-0,766$ & $-0,700$ & $-46,082$ & $-1,132$ \\
\hline 2006 & 69 & 2296,556 & 6,40 & $-0,235$ & $-0,239$ & $-1,563$ & $-1,313$ & $-5,193$ & $-0,358$ & $-0,383$ & $-0,006$ \\
\hline 2007 & 67 & 770,615 & $3,830 * *$ & $-0,188$ & $-0,369$ & $-0,290$ & $-0,506$ & $-3,247$ & $-1,039$ & $-46,454$ & $-1,549$ \\
\hline 2008 & 62 & 1,472 & 0,014 & $-0,270$ & $-0,792$ & $-0,426$ & $-1,222$ & $-2,017$ & $-2,081 * *$ & $-35,016$ & $-1,991 * *$ \\
\hline
\end{tabular}

\begin{tabular}{|c|c|c|c|c|c|c|c|c|c|c|c|c|}
\hline \multicolumn{2}{|c|}{$\log (S)_{t-1}$} & \multicolumn{2}{|c|}{$O w n P T_{t-1} \%$} & \multicolumn{2}{|c|}{$O w n P_{t-1} \%$} & \multicolumn{2}{|c|}{$O w n M_{t-1} \%$} & \multicolumn{2}{|c|}{$O w n A_{t-1} \%$} & \multirow{2}{*}{$F$} & \multirow{2}{*}{ Sig. $F$} & \multirow{2}{*}{$R^{2}$} \\
\hline$f$ & $t(f)$ & $g$ & $t(g)$ & $h$ & $t(h)$ & $i$ & $t(i)$ & $j$ & $t(j)$ & & & \\
\hline \multicolumn{13}{|c|}{ Panel A: Market Book Value \% } \\
\hline $\begin{array}{l}-37,748 \\
\end{array}$ & $-2,682 * *$ & 0,473 & 1,404 & $-0,728$ & $-1,277$ & $-0,137$ & $-0,325$ & $-0,452$ & $-1,200$ & 2,837 & 0,008 & 0,317 \\
\hline$-16,429$ & $-1,539$ & 0,141 & 0,575 & 0,051 & 0,131 & $-0,132$ & 0,386 & $-1,072$ & $-3,555^{* *}$ & 6,120 & 0,000 & 0,466 \\
\hline 69,648 & $4,134 * *$ & $-0,712$ & $-1,539$ & $-0,740$ & $-1,159$ & $-0,744$ & $-1,155$ & $-1,269$ & $-2,257 * *$ & 4,344 & 0,000 & 0,365 \\
\hline 24,245 & $2,536^{* *}$ & $-0,457$ & $-1,617$ & $-1,306$ & $-3,331 * *$ & $-0,939$ & $-2,299 * *$ & $-1,070$ & $-3,525^{* *}$ & 35 & 0,000 & 0,399 \\
\hline 14,791 & $2,216 * *$ & 0,196 & 0,954 & $-0,126$ & $-0,487$ & 0,057 & 0,172 & $-0,318$ & $-1,465$ & 3,441 & 0,002 & 0,330 \\
\hline 8,523 & 1,629 & 0,048 & 0,311 & 0,134 & 0,543 & $-0,297$ & $-1,005$ & $-0,315$ & $-1,919 *$ & 7,701 & 0,000 & 0,549 \\
\hline 5,704 & 0,960 & $-0,460$ & $-2,061 * *$ & $-0,662$ & $-2,064 * *$ & $-0,408$ & $-0,875$ & $-0,988$ & $-3,943 * *$ & 6,217 & 0,000 & 0,465 \\
\hline 43,357 & $3,507 * *$ & 0,271 & 0,349 & 0,991 & 1,156 & 1,888 & 1,141 & $-0,116$ & $-0,145$ & 55 & & 0,326 \\
\hline 45,264 & $2,886 * *$ & 1,743 & $1,655^{*}$ & 1,058 & 0,975 & 3,150 & 1,125 & 1,847 & $1,752 *$ & 2,204 & & 0,262 \\
\hline 14,019 & $2,014 * *$ & 0,147 & 0,424 & $-0,145$ & $-0,392$ & 0,375 & 0,443 & $-0,142$ & $-0,396$ & 2 & & 0,349 \\
\hline 21,932 & 4,395 & 0,014 & 0,083 & $-0,281$ & $-1,329$ & $-0,002$ & $-0,006$ & $-0,232$ & $-1,256$ & & & 0,476 \\
\hline & 2,249 & 214 & & $-0,040$ & $-0,116$ & 1,540 & & 0,055 & 0,221 & & & 269 \\
\hline 63,397 & $2,206 * *$ & 15,947 & $-6,617 *$ & $-15,589$ & $-6,206^{* *}$ & $-15,089$ & $-4,561 * *$ & $-14,938$ & $-6,172 * *$ & 6,926 & & 0,505 \\
\hline 91,805 & $2,755^{*} *$ & $-26,219$ & $-9,335^{*}$ & $-26,602$ & $-9,153 * *$ & $-25,829$ & $-6,851 * *$ & $-25,979$ & $-8,902 * *$ & 12,593 & & 0,658 \\
\hline 29,260 & 1,636 & $-7,880$ & $-5,155^{* *}$ & $-7,637$ & $-4,855^{* *}$ & $-7,869$ & $-4,031 * *$ & $-7,471$ & $-4,798 * *$ & & & 0,445 \\
\hline 31,805 & $2,943 * *$ & $-0,144$ & $-0,169$ & $-0,519$ & $-0,591$ & $-1,273$ & $-1,057$ & 0,127 & 0,149 & 3,076 & 0,005 & 0,347 \\
\hline
\end{tabular}

Keterangan: *) signifikan pada $\alpha=10 \%$; **) signifikan pada $\alpha=5 \%$ 


\section{Simpulan dan Implikasi}

Berdasarkan hasil analisis diperoleh kesimpulan bahwa variabel yang paling mempengaruhi nilai perusahaan selama tiga situasi ekonomi secara konsisten yaitu ukuran perusahaan. Keputusan tidak membayar dividen menghasilkan kesimpulan sama pada periode selama krisis dan setelah krisis. Kesimpulan ini dapat menjelaskan bahwa ukuran perusahaan merupakan faktor penting yang dipertimbangkan investor dalam melakukan investasi di pasar modal. Semakin besar ukuran suatu perusahaan dianggap makin tinggi nilai perusahaan. Kebijakan tidak membayar dividen pada dua situasi pengaruhnya tidak searah terhadap nilai perusahaan. Oleh karena itu, dapat disimpulkan bahwa apabila suatu perusahaan tidak membayar dividen, maka nilai perusahaan akan semakin turun. Hal ini dapat diartikan bahwa investor lebih menginginkan perusahaan untuk melakukan membayar dividen kas daripada tidak membayar dividen. Dalam dua situasi ekonomi, yaitu selama krisis dan setelah krisis, variabel kebijakan pendanaan perusahaan memiliki kontribusi yang paling kecil dalam peningkatan nilai perusahaan. Hasil ini menunjukkan bahwa kebijakan pendanaan apapun yang dilakukan oleh perusahaan tidak mampu mempengaruhi investor dalam melakukan investasi di pasar modal. Selain itu, nilai perusahaan memiliki perbedaan yang signifikan sesuai dengan situasi ekonomi yang diamati dalam penelitian ini.

Implikasi penelitian yang dapat dilakukan bagi perusahaan publik khususnya manufaktur bahwa ukuran perusahaan penting untuk diperhatikan guna meningkatkan nilai perusahaan. Perusahaan dapat melakukan dengan cara investasi yang prospektif dengan menggunakan sumber pembiayaan eksternal yang memadai. Bagi investor, ukuran perusahaan bukan satu-satunya faktor penentu untuk meningkatkan nilai perusahaan. Akan tetapi, perusahaan tetap harus memperhatikan faktor lainnya seperti variabel pelaksanaan good corporate governance, profitabilitas dan pertumbuhan perusahaan di masa yang akan datang.

\section{Daftar Referensi}

Barclay, M., \& Holderness, C. (1990). Social responsiveness, corporate structure, and economic performance. Academy of Management Review, 7, 235-241.

Barclay, M. J., Smith, C. W., \& Watts, R. L. (1998). The determinations of corporate leverage and dividend policies. Dalam The New Corporate Finance. $2^{\text {nd }}$ Edition. Malaysia: Irwin Mc-Graw-Hill.
Baskin, J. (1989). An empirical investigation of the pecking order hypothesis. Journal of Financial Management Association, 18(1), 26-35.

Bathala, C. T., Moon, K. P., \& Rao, R. P. (1994). Managerial ownership, debt policy and the impact of institutional holdings: An agency perspective. Financial Management, 23, 38-50.

Baxter, N. D., \& Cragg J. G. (1970). Corporate choice among long-term financing instruments. The Review of Economics and Statistics, 2(3), 225235.

Brickley, J. (1983). Shareholder wealth, information signaling and the specially designated dividend: An empirical study. Journal of Financial Economics, 12(2), 187-209.

Brigham, E. F., Gapenski, L. C., \& Daves, P. R. (2006). Intermediate financial management. $9^{\text {th }}$ Edition. Florida: Dryden Press.

Claessens, S., Djankov, S., \& Lang, L. H. P. (2000). Separation of ownership and control in East Asean Corporation. Journal of Financial Economics, 58, 81-112.

DeAngelo, H., \& Masulis R. W. (1980). Optimal capital structure under corporate and personal taxation. Journal of Financial Economics, 8, 329.

Demsetz, H., \& Lehn, K. (1985). The structure of corporate ownership causes and consequences. Journal of Political Economy, 93, 1155-1177.

Easterbrook, F. H. (1984). Two agency-cost explanation of dividends. American Economic Review, 74(4), 650-659.

Fama, E. F., \& Jensen, M. C. (1983). Separation of ownership firm control. Journal of Law and Economics, 26(2), 301-325.

Himmelberg, C. P., Hubbard, R. G., \& Palia, D. (1999). Understanding determinants of managerial ownership and the link between ownership and performance. Journal of Financial Economics, 53, 353-384.

Holderness, C., Kroszner, R., \& Sheehan, D. (1999). Were the good old times that good? Changes on managerial stock ownership since the great depression. Journal of Finance, 54(2), 435-469.

Jensen, M. C., \& Meckling, W. H. (1976). Theory of the firm: Managerial behaviour, agency costs and ownership structure. Journal of Financial Economics, 3, 305-360.

Kim, E. H. (1978). A mean-variance theory of optimal capital structure and corporate debt capacity. The Journal of Finance, 33(1), 45-63.

Kraus, A., \& Litzenberger R. H. (1973). A statepreference model of optimal financial leverage. The Journal of Finance, 28(4), 911-922. 
La Porta, R., Lopez, F., Shleifer, A., \& Vishny, R. W. (1999). Corporate ownership around the world. The Journal of Finance, 54, 471-517.

Leff, N. (1978). Industrial organization and entrepreneurship in the developing countries: The economics group. Economic Development and Cultural Change, 4.

Lemmon, M. L., \& Lins, K. V. (2003). Ownership structure, corporate governance, and firm value: Evidence from the East Asian financial crisis. The Journal of Finance, 58(4), 1445-1468.

Levy, H., \& Sarnat, M. (1990). Capital investment and financial decision. $4^{\text {th }}$ Edition. New York: Prentice-Hall Inc.

Lins, K. V. (2003). Equity ownership and firm value in emerging markets. Journal of Financial and Quantitative Analysis, 38(1), 159-184.

McConnell, J. J., \& Servaes, H. (1995). Equity ownership and two faces of debt. Journal of Financial Economics, 39, 131-157.

Miller, M. (1977). Debt and taxes. Journal of Finance, 32(2), 261-275.

Modigliani, F. \& Miller, M. (1958). The cost of capital, corporation finance and the theory of investment. American Economic Review, 48(3), 261-297.

(1963). Taxes and the cost of capital: A correction. American Economic Review, 53(3), 433-443.

Moh'd, M. A., Perry, L. G., \& Rimbey, J. N. (1998). The impact of ownership structure on corporation debt policy: A time-series cross-sectional analysis. The Financial Review, 33, 85-98.

Morck, R. A., Shleifer, A., \& Vishny, R. W. (1988). Management ownership and market valuation. Journal of Financial Economics, 20, 293-315.

Mueller, H. M., \& Warneryd, K. (2001). Inside versus outside ownership: A political theory of firm. RAND Journal of Economics, 32(3), 527-541.

Myers, S. C. (2001). Capital structure. The Journal of Economic Perspectives, 15(2), 81-102.

Putterman, L. (1993). Ownership and the nature of firm. Journal of Comparative Economics, 17(2), 243-263.
Prasetyorini, B. F. (2013). Pengaruh ukuran perusahaan, leverage, price earning ratio dan profitabilitas terhadap nilai perusahaan. Jurnal Ilmu Manajemen, 1(1), 183-196.

Rachmawati, A., \& Triatmoko, H. (2007). Analisis faktor-faktor yang mempengaruhi kualitas laba dan nilai perusahaan. Makassar: Simposium Nasional Akuntansi $X$.

Rajan, R. G., \& Zingales, L. (1995). What do we know about capital structure? Some evidence from international data. Journal of Finance, $L(5), 1421-1460$.

Salvatore, D. (2005). Ekonomi manajerial dalam perekonomian global. Edisi 5. Jakarta: Salemba Empat.

Scharfstein, D. S. (1998). The dark side of internal capital markets II: Evidence from diversified conglomerates. NBER Working Paper, 6352.

Short, H., \& Keasey, K. (1999). Managerial ownership and the performance of firms: Evidence from the UK. Journal of Corporate Finance, 5, 79-101.

Stiglitz, J. E. (1972). A re-examination of the modigliani-miller theorem. American Economic Review, 59(5) 784-793.

Soliha, E., \& Taswan. (2002). Pengaruh kebijakan hutang terhadap nilai perusahaan serta beberapa faktor yang mempengaruhinya. Jurnal Bisnis dan Ekonomi, 9, 149-163.

Sujoko, \& Soebiantoro, U. (2007). Pengaruh struktur kepemilikan saham, leverage, faktor intern dan faktor ekstern terhadap nilai perusahaan. Jurnal Manajemen dan Kewirausahaan. 9(1), 41-48.

Thies, C. F., \& Klock, M. S. (1992). Determinant of capital structure. Review of Financial Economics, 1(2), 40-53.

Titman, S., \& Wessels, R. E. (1988). Determinants of capital structure choice. Working paper. Los Angeles: University of California.

Wiwattanakantang, Y. (2001). The equity ownership structure of Thai firms. Working Paper. Tokyo, Japan: Center for Economic Institutions, Institute of Economic Research, Hitotsubashi University. 